\title{
Cortem-lhe a cabeça: a atualidade desse enunciado mutilando corpos e subjetividades
}

\author{
Off with their heads: the currentness of this statement mutilating bodies and \\ subjectivity \\ Denise Gabriel WITZEL \\ Universidade Estadual do Centro-Oeste do Paraná - UNICENTRO
}

https://orcid.org/0000-0002-4685-7574

\begin{abstract}
RESUMO: Partimos da centralidade do conceito de enunciado na obra "A Arqueologia do Saber", de Michel Foucault, articulando-o com as relações inescapáveis entre discurso, corpo e poder, com o objetivo primordial de analisar o acontecimento discursivo do enunciado Cortemlhe a cabeça, amplamente conhecido a partir dos gritos bradados pela Rainha de Copas em direção a todos os súditos considerados insolentes no clássico "Alice no País das Maravilhas", de Lewis Carroll. Interessa-nos a atualidade desse grito dirigido às mulheres dadas como "insolentes", determinando-lhes sua execução/decapitação. Nossas reflexões privilegiam a rede de sentidos tramada em torno do significante "cabeça" transformado, historicamente, em símbolo de poder e justiça no bojo do poder soberano e, em certa medida, no bojo do poder patriarcal. Nessa direção, descrevemos as materialidades do nosso corpus - constituído por casos de feminicídio/decapitação propagados na grande mídia - em consonância com o espaço de memória que elas convocam, examinando as condições sócio-históricas de existência e de circulação do enunciado Cortem-lhe a cabeça, as posições de sujeito ali apontadas e as especificidades das materialidades que dão corpo aos sentidos. Destacamos, por fim, as articulações que esse enunciado estabelece com a história das mulheres e a memória, (re)produzindo antigas práticas de mutilação de corpos e de subjetividades.
\end{abstract}

PALAVRAS-CHAVE: Arqueologia do Saber. Decapitação. História das mulheres

ABSTRACT: we start from the centrality of the statement concept in the work Archaeology of Knowledge, by Foucault, articulating it with the inescapable relationships between discourse, body and power, with the primary objective of analyzing the discoursive event of the statement "Off with their heads", widely known from the cries shouted by the Queen of Hearts towards all subjects considered insolent in the classic Alice in Wonderland, by Louis Carrol. We are interested in the currentness of this cry directed at women considered "insolent", determining their execution/beheading. Our reflections privilege the network of meanings woven around the significant "head" transformed, historically, as a symbol of power and justice in the midst of the sovereign power and, to some extent, in the midst of the patriarchal power. In this direction, we describe the materialities of our corpus - constituted by a case of femicide / beheading reported on media - in line with the space of memory that they summon, examining the socio-historical conditions of existence and circulation of the statement "off with their head", the subject positions pointed there and the specificities of the materialities that embody the meanings. Finally, we highlight the articulations that this statement establishes with the history of women and the memory, (re) producing old practices of bodies and subjectivities mutilation.

KEYWORDS: Archaeology of knowledge. Beheading. History of women, 


\section{INTRODUÇÃO}

A Rainha ficou vermelha de raiva e, depois de olhar para ela um momento como uma fera selvagem, urrou com voz esganiçada: Cortem-lhe a cabeça! Cortem-lhe a... Disparate! Disse Alice decidida, em alto e bom som, e a rainha se calou. O Rei pôs a mão em seu ombro e disse timidamente: Pense bem, minha cara; é apenas uma criança. (CARROLL, 2007, p. 136, grifos nossos)

A citação com que inicio este texto destaca a personagem Alice desafiando a temida Rainha de Copas ao tempo em que a monarca, arbitrariamente, ordena sua decapitação e decreta a sentença antes do julgamento, conforme rege sua lógica. São largamente conhecidas essas personagens do clássico Alice no País das Maravilhas, de Lewis Carroll (Charles Lutwidge Dodgson), publicado em 1865, na Inglaterra do período vitoriano, época em que o poder soberano da "icônica" rainha Vitória (18371901) imprimiu na história rígidos modelos de valores morais e conservadores.

No conjunto da obra carrolineana, a insistente repetição do enunciado Cortemlhe a cabeça satiriza e denuncia a soberania monárquica cujos poderes - brilhantes, ilimitados, pessoais, irregulares e descontínuos - incidem sobre a vida e a morte dos indivíduos (FOUCAULT, 2005, p.108). Trata-se de um poder que parte do princípio de que a origem do monarca é divina e, por ter sido escolhido por Deus, o rei seria um ser sábio e justo. E porque sábio e justo, seria natural ele decidir pela vida ou pela morte de seus súditos. Foucault (2005) diz que a soberania se caracteriza pelo imperativo "deixar viver ou fazer morrer" traduzido, na narrativa da Rainha de Copas, por "cortar a cabeça ou não cortar a cabeça”. Qual a atualidade dessa soberania que (re)produz, ainda hoje, práticas de decapitação? Pergunta que nos colocamos aqui considerando que se é uma sátira, é porque há exemplos concretos a serem satirizados e, por conseguinte, discursivizados.

Face às múltiplas chaves de leitura da obra carroliniana e aos possíveis deslocamentos que nos conduzem para muito além da toca do coelho - e do universo nonsense, lúdico, fantástico e ficcional da belíssima narrativa da Alice - propomo-nos, aqui, descrever e analisar arqueologicamente o enunciado destacado, articulando-o com as relações inescapáveis entre discurso, corpo e poder (FOUCAULT, 2005), tendo em conta que

[...] é preciso estar pronto para acolher cada momento do discurso em sua irrupção de acontecimentos, nessa pontualidade em que aparece e nessa dispersão temporal que lhe permite ser repetido, sabido, esquecido, transformado, apagado até nos menores traços, escondido bem longe de todos os olhares, nas poeiras dos livros. Não é preciso 
remeter o discurso à longínqua presença da origem; é preciso tratá-lo no jogo de sua instância (FOUCAULT, 2007, p.28).

Interessa-nos, pois, acolher o enunciado compreendido como a unidade elementar do discurso que abre "para si mesmo uma existência remanescente no campo de uma memória, ou na materialidade dos manuscritos, dos livros e de qualquer forma de registro" (FOUCAULT, 2007, p. 31-32). Em suma, Cortem-lhe a cabeça, quando dirigido às mulheres, como mostraremos mais à frente, coexiste com outros enunciados num campo associado, todos articulados entre si por meio de práticas culturais, sociais, políticas e econômicas, ligando-se a uma memória formatada ao longo da história das mulheres por saberes e poderes produtores de verdades sobre o sujeito, seu corpo... sua cabeça.

Como e por que o que é considerado verdade sobre o corpo das mulheres, conduzindo-as à morte e à decapitação, se tornou um dia em algo verdadeiro? Possíveis respostas a essa inquietação ancoram-se, neste estudo, nos pressupostos teóricos e metodológicos da Arqueologia do Saber, sem perder de vista o alerta de Foucault (2007): embora o título da obra aponte para o tema da "origem" (arké, em grego significa começo) e para a noção de "escavação" que buscaria relações secretas, escondidas, trata-se, antes, de uma busca por "começos relativos", visando, fundamentalmente, "definir relações que estão na própria superfície dos discursos; [...] tornar visível o que só é invisível por estar muito na superfície das coisas" (FOUCAULT, 2007, p.146). Isso porque, nada há sob os documentos; o que há são somente enunciados e relações.

Voltamo-nos, pois, analiticamente para os enunciados e as relações, a partir de casos de feminicídios relatados na grande mídia, seguindo alguns passos precisos de Michel Foucault, quando ele se interessa particularmente pela vida dos homens infames (FOUCAULT, 2006), ou seja, vidas anônimas e paralelas que só se manifestam em choque com o poder.

Foucault (1994) retoma Plutarco para sublinhar que os antigos gostavam de colocar em paralelo as vidas dos homens ilustres. Lembra que as paralelas são feitas para se reunirem no infinito, mas propõe considerar outras que, indefinidamente, divergem. 
Pas de point de rencontre ni de lieu pour les recueillir. Souvent elles n'ont eu d'autre écho que celui de leur condamnation. Il faudrait les saisir dans la force du mouvement qui les sépare ; il faudrait retrouver le sillage instantané et éclatant qu'elles ont laissé lorsqu'elles se sont précipitées vers une obscurité où «ça ne se raconte plus » et où toute «renommée » est perdue. Ce serait comme l'envers de Plutarque : des vies à ce point parallèles que nul ne peut plus les rejoindre (FOUCAULT, 1994, p. 499). ${ }^{1}$

Em meio a sua antologia da existência de vidas paralelas, ele deu visibilidade ao parricida Pierre Rivière (1815-1840) ${ }^{2}$, um jovem camponês que, ao degolar a mãe - também grávida -, a irmã e o irmão, em 1835, animou um complexo processo penal no qual, pela primeira vez, estabeleceram-se relações entre a psiquiatria e a justiça penal, entre a loucura e o crime.

No nosso entendimento, a exemplo de Pierre, outros sujeitos discursivos da atualidade protagonizam outros acontecimentos a partir dos quais emerge certa regularidade e recursividade de sentidos em meio à dispersão de discursos em torno do enunciado Cortem-lhe a cabeça. Para analisá-lo, elegemos como "princípio de diferenciação" (FOUCAULT, 2007) a relação entre a simbologia da cabeça cortada e o dispositivo do poder patriarcal que traz as marcas constitutivas do poder soberano da rainha de copas, impondo o imperativo "deixe viver" ou "deixe morrer".

Da invisibilidade de corpos - no tempo de Pierre Rivière - à sua hipervisibilidade na web - nos atuais tempos - instaura-se um novo modo de funcionamento do "olho do poder", no sentido panóptico da expressão. Trata-se, agora, de um "olhar coletivo", "imediato" e "anônimo" que nos leva a descrever e analisar as formas contemporâneas do que Foucault escreveu sobre famoso parricida:

$\mathrm{O}$ assassinato ronda nos confins da lei, aquém ou além da lei, acima ou abaixo; ele gira ao redor do poder ora contra ele, ora com ele. A narrativa do assassinato instala-se nesta região perigosa da qual utiliza a reversibilidade: comunica o proibido com a submissão, o anonimato com o heroísmo; por ela a infâmia toca a eternidade. (FOUCAULT, 1977, p. 117)

\footnotetext{
${ }^{1}$ Tradução livre: Sem ponto de encontro, nem lugar para as recolher. Frequentemente elas não tiveram outro eco senão o de sua condenação. Seria necessário apanhá-las na força do movimento que as separa; seria necessário redescobrir o rastro instantâneo e fulgurante que elas deixaram quando se precipitaram para uma obscuridade onde "isso já não conta" e onde todo o "renome" é perdido. Seria como o inverso de Plutarco: vidas a tal ponto paralelas que já ninguém as pode reunir.

${ }^{2}$ Além do memorial de Pierre Rivière, publicado em 1973, Michel Foucault interessou-se igualmente pelo livro do libertino inglês autor de My Secret Life, em 1977. Editou, na sequência, o volume contendo "as lembranças" de Herculine Barbin dite Alexina B. e um dossiê com alguns documentos referentes ao trágico destino dessa hermafrodita do século XIX que não suportou viver os sofrimentos de um corpo duplo em uma época em que o hermafroditismo era concebido como uma anomalia anatômica e fisiológica. Por último, publicou em 1982, com Arlette Farge, Le désordre des familles. Lettres de cachet des Archives de la Bastille.
} 


\section{Breve história da simbologia da cabeça cortada}

A decapitação é uma prática muito antiga e muito atual. Em um breve retorno à história, deparamo-nos com um arquivo - ou seja, tudo o que foi efetivamente dito em um momento histórico (FOUCAULT, 2007) - constituído por diferentes saberes que objetivaram/subjetivaram os sujeitos a partir da compreensão de que a "cabeça" liga-se fortemente ao princípio ativo de governar, ordenar, instruir, liderar etc. Se considerarmos o pensamento mítico - quer seja pelo mito da Medusa quer seja pela prática cara aos Celtas de guardar a cabeça de seus inimigos de alta reputação sabemos que a essa parte do corpo se atribuíam poderes mágicos e curativos. Crenças (verdades historicamente construídas) que se prolongaram ao longo das eras.

O mito grego da Medusa integra a memória coletiva e discursiva a partir da imagem da cabeça decapitada. Medusa era uma das três irmãs Górgonas que possuía cabelos de cobras e um rosto horripilante. Quem a mirasse era petrificado. Perseu foi o único que conseguiu se aproximar do monstro, usando o seu escudo como espelho. Medusa fica horrorizada ao ver seu rosto refletido e lança um grito dilacerante. Perseu mata Medusa e entrega sua cabeça à Atena, que a coloca em um escudo, aegis, e passa a levá-la em suas batalhas de modo a amedrontar os inimigos e derrotá-los.

Sua famosa cabeça, derivada do mito, se associou à imagem da deusa da estratégia e da guerra justa, detentora de grande sabedoria. Ela foi eternizada em inúmeras narrativas literárias e em obras de arte, como esta icônica "Cabeça da Medusa" (1597), de Caravaggio

Figura 1: Cabeça de Medusa, de Caravaggio (1597)

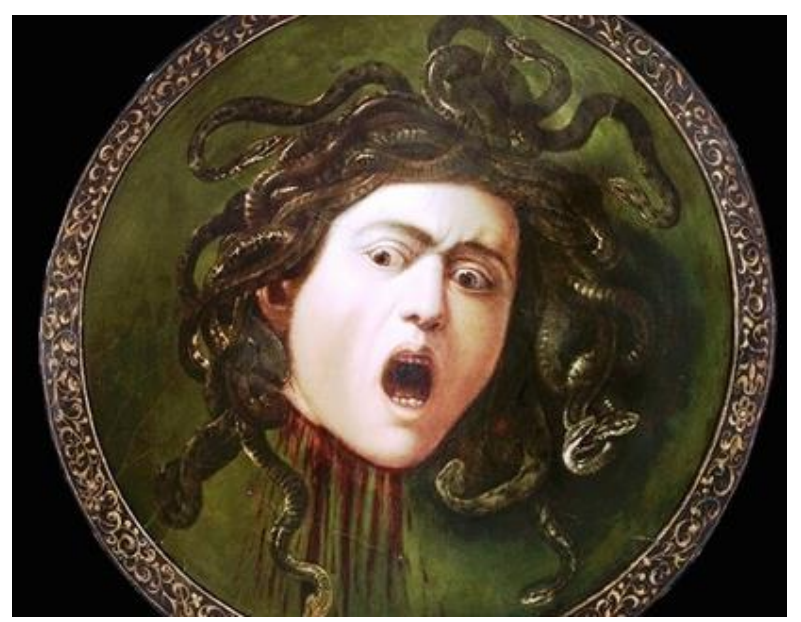

Fonte: <https://www.historiadasartes.com/sala-dos-professores/cabecade-medusa-caravaggio/ $>$ 
Para além das narrativas míticas gregas, há vários indícios, segundo Zierer (2011, p. 112), de que os antigos povos Celtas valorizavam a cabeça cortada entendendo que ela poderia "transmitir poder a quem a possuísse, ser fonte geradora da vida, ao transmitir a alma de um corpo a outro, ter poder de cura e de aterrorizar os inimigos". Notadamente sobre a convicção de que na cabeça estava presa a força e o valor do adversário que eram transmitidos àquele que a possuía, destacamos o relato abaixo.

Quando seus inimigos caíam, eles cortavam-lhes as cabeças e as amarravam aos pescoços de seus cavalos; e entregando aos seus auxiliares as armas dos seus oponentes, todas cobertas de sangue, as carregavam como botim, começando a cantar um hino sobre elas e uma canção de vitória, e todas essas primícias de batalha eles prendiam por cordões em suas casas, como os homens fazem, em certos tipos de caça, com as cabeças das bestas ferozes que haviam capturado. As cabeças dos inimigos mais famosos eram embalsamadas em óleo de cedro e cuidadosamente preservadas em uma caixa, e isso eles exibiam aos estrangeiros [...]. E alguns homens entre eles, segundo nos foi contado, se vangloriavam de nunca haver aceitado o pagamento de igual quantia em ouro pela cabeça que mostravam, como a significar um tipo bárbaro de grandeza de espírito, pois não vendê-las significava o testemunho e prova do seu valor [...]. (DIODORUS SICULUS, apud ZIERER, 2011, p. 119)

O guerreiro celta, ainda segundo Zierer (2011), costumava ostentar a cabeça do inimigo em seus carros de guerra, valendo-se de gritos para aterrorizar o oponente, a exemplo dos gritos guerreiros de Atena e o grito estridente da Medusa. Note-se que apenas as cabeças dos inimigos homens eram cortadas. Ao acreditarem que o poder gerador da vida estaria ligado somente ao esperma, à virilidade masculina, eles fundamentaram a premissa de que a continuidade genética estaria exclusivamente no sexo masculino: "só eram cortadas as cabeças do inimigo masculino, estando reservado às mulheres o corte dos seios, para que a sua geração não tivesse continuidade através do líquido gerador - associado ao esperma - ou alimentador - o seio. (ZIERER, 2011, p.120).

A ostentação pública das cabeças dos inimigos, valorizada nos povos antigos, é uma prática que não permanece em um passado tão distante. Como forma tanto de expor suas vitórias quanto de intimidar eventuais oponentes, são famosas as cabeças do bando de Lampião que ficaram expostas, em 1938, nos degraus da escadaria do Palácio Dom Pedro II, atual sede da prefeitura de Piranhas-AL. 


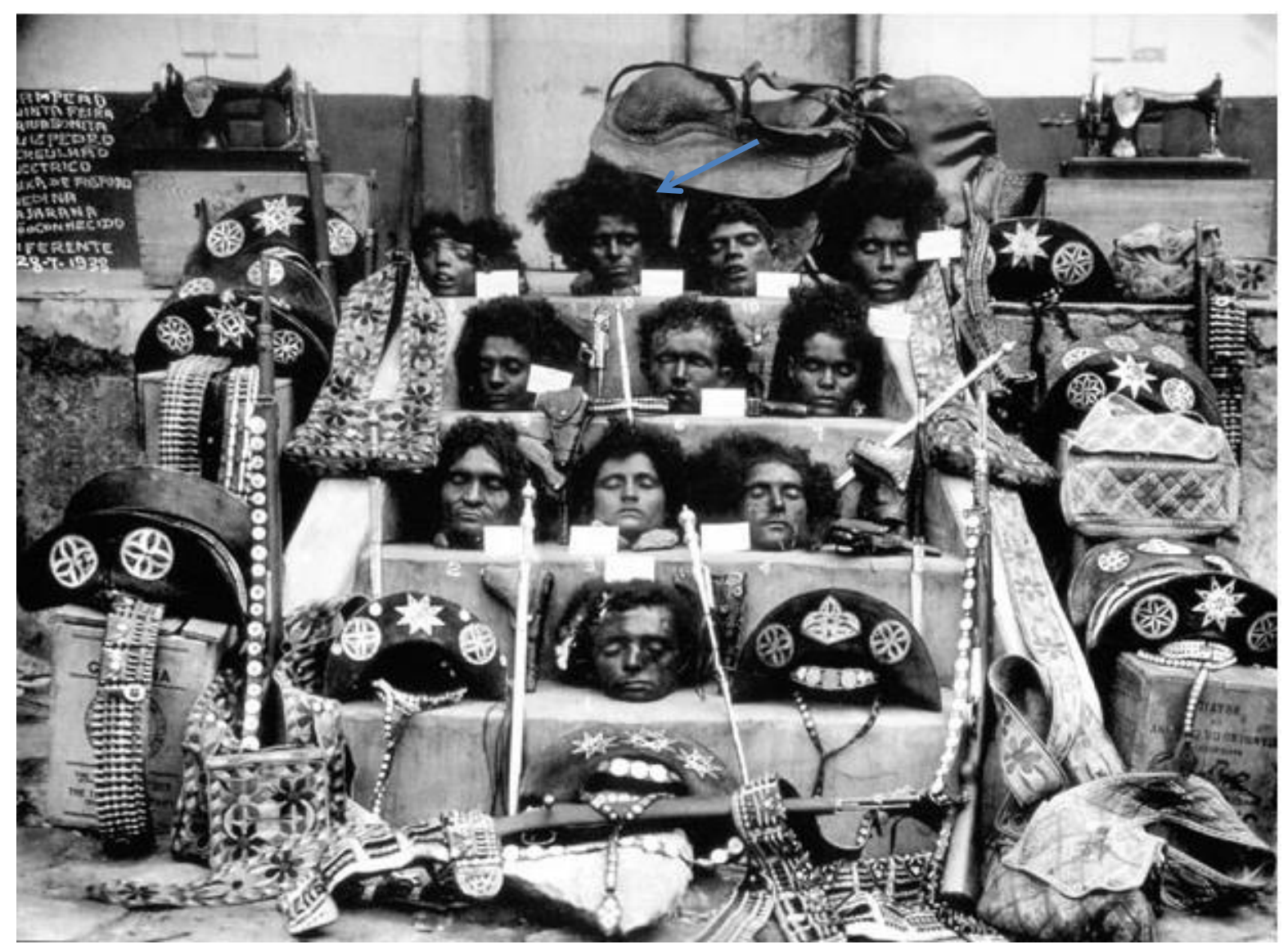

Fonte: <https://m.folha.uol.com.br/ilustrissima/2017/12/1939639-fotos-da-guerra-do-cangaco-revelamlado-desconhecido-de-lampiao.shtml $>$

Nessa imagem, vemos muito bem organizadas - notem-se os chapéus, rifles e outros objetos do grupo - as cabeças do rei do cangaço, Lampião (no primeiro degrau), e de sua companheira, Maria Bonita (destacada no meio do segundo degrau), acompanhadas de outros nove integrantes do bando. Na madrugada de 28 de julho de 1938, o bando foi surpreendido por soldados da Polícia Militar, na Gruta do Angico, atual Poço Redondo/SE, e, os que não conseguiram fugir, foram mortos e decapitados. Alguns, como Maria Bonita, foram decapitados ainda vivos: “ o soldado Godoy ignorou os suplícios da cangaceira para que a deixasse viver [...] ele não se sensibilizou. Com um só golpe arrancou-lhe a cabeça, ainda viva" (NEGREIROS, 2018, p.233). Todos os corpos decapitados foram deixados no local para serem consumidos pelos urubus e o de Maria Bonita, fazendo jus a um corpo historicamente saturado de sexualidade e, por isso, subjugado, teria sido "abandonado com as pernas abertas e um pedaço de madeira enfiado na vagina" ( NEGREIROS, 2018, p.235). 
As cabeças foram levadas dentro de latas de querosene, em cima de um caminhão, de modo a intimidar aqueles que seguiam, ou pensavam em seguir, os ideais do monarca da caatinga. O cortejo saiu da cidade de Piranhas-AL, passando por diversas cidades e lugarejos, até chegarem a Maceió-AL. Temos aí, portanto, um ritual inspirado nas antigas formas de aterrorizar os inimigos em que a cabeça cortada é tomada como um símbolo de "triunfo".

Elas se tornaram objeto de análise de vários médicos, com o intuito de se descobrir se havia alguma anomalia, degeneração, patologia ou desvios que apontassem para a criminalidade. Ficaram expostas no Museu Antropológico Estácio de Lima, em Salvador, por mais de três décadas. Foram, finalmente, inumadas por ordem judicial. As cabeças de Lampião e Maria Bonita foram sepultadas no dia 6 de fevereiro de 1969 e as demais, uma semana depois.

Poderíamos retomar muitos outros acontecimentos em que a cabeça equivale a um triunfo/troféu: a de João Batista (2 a.C.-28 d.C.), por exemplo, entregue numa bandeja de prata a Salomé, segundo a narrativa bíblica; ou a de Tiradentes (1746-1792), exposta em Praça Pública para apodrecer até que o tempo a consumisse, mas que foi roubada e nunca mais foi localizada. Outras, menos conhecidas, somam-se a essa valorização da cabeça cortada dos inimigos, como ocorria em certos povos indígenas.

Os Shuars, por exemplo, são povos da região amazônica hoje pertencente ao Equador e ao Peru. Eles acreditavam na vida após a morte e, segundo suas crenças, um inimigo morto permanecia vivo dentro de sua cabeça. Cortá-la e guardá-la significava se empoderar do espírito do vencido e evitar que houvesse vingança após sua morte. Essas cabeças cortadas eram encolhidas e transformadas em uma espécie de talismã conhecidos como Tsantsa ${ }^{3}$ - utilizado por um período de aproximadamente um ano, tempo que o espírito inimigo demorava para ir embora.

Michel Foucault também se interessou pelos "poderes mágicos da cabeça" em seu belo texto $O$ Corpo Utópico, uma das conferências radiofônicas que ele proferiu em 1966 pela Radio France Culture, publicada em Foucault (2013). Para explicar o corpo utópico, ele parte do princípio de que o corpo "é o contrário de uma utopia", pois ele “jamais se encontra sob outro céu, lugar absoluto, pequeno fragmento de espaço com o qual, no sentido estrito, faço corpo" (FOUCAULT, 2013, p.7). Corpo é lugar e por isso mesmo não é utopia. E é um lugar inevitável, irremediável; ele nos acorrenta, antes e

\footnotetext{
${ }^{3}$ Matéria sobre a A origem da prática de tribo sul-americana de encolher a cabeça de seus inimigos. Disponível em https://www.bbc.com/portuguese/geral-40302750. Acesso em set., 2019.
} 
depois da nossa morte, sendo-nos impossível nos desvencilhar. A utopia, por sua vez, é pensada como o lugar fora de todos os lugares, onde se encontra a beleza e o deslumbramento - seria um corpo incorporal. Foucault designa nosso corpo, por ser o lugar irremediável a que estamos condenado, como corpo-túmulo, corpo-cárcere, corpoprisão, corpo-carcaça.

Essa "topia implacável" é negada no texto a partir do momento em que Foucault, dialeticamente, localiza no corpo a origem de todas as utopias. Ela está nele. Ou seja, o não-lugar está no lugar-nenhum. Para comprovar que as utopias nascem do corpo e, na sequência, voltam-se contra ele, Foucault (2013) convoca três elementos: a cabeça, o espelho e o cadáver.

A cabeça é uma "estranha caverna aberta para o mundo exterior", porque possui aberturas. E nessa cabeça, pergunta-se: “como acontecem as coisas?" A visão e a audição, por exemplo, ao permitirem a circulação entre os espaços de fora e dentro do corpo, faz com que as coisas que vemos entrem na cabeça, mas elas permanecem fora. O mesmo raciocínio vale para a questão: onde estamos quando estamos pensando? Desse modo, a utopia aí se instala. O não-lugar ganha lugar que, enfim, é o corpo. A cabeça, enfim, seria um ponto de partida e de chegada de utopias, talvez de todas as utopias, -lugar, no lugar-algum.

Quanto ao espelho ${ }^{4}$ e ao cadáver:

[eles] asseguram um espaço para experiência profundamente e originariamente utópica do corpo; espelho e cadáver é que silenciam e serenizam, encerrando em uma clausura - que, para nós, hoje, é selada - esta grande cólera utópica que corrói e volatiliza nosso corpo a todo instante. Graças a eles, graças ao espelho e ao cadáver, é que nosso corpo não é pura e simples utopia. Ora, se considerarmos que a imagem do espelho está alojada para nós em um espaço inacessível, e que jamais poderemos estar lá onde estará o nosso cadáver, se considerarmos que o espelho e o cadáver estão, eles próprios, em um inatingível outro lugar, descobrimos então que unicamente as utopias podem fazer refluir nelas mesmas e esconder por um instante a utopia profunda e soberana de nosso corpo. (FOUCAULT, 2013, p. 15)

\footnotetext{
${ }^{4}$ Em seu texto, Os outros espaços, Foucault discute o conceito de heterotopia, argumentando que entre as utopias e as heterotopias existe uma espécie de união análoga a de um espelho, pois: [...] no espelho, eu me vejo lá onde não estou, em um espaço irreal que se abre virtualmente atrás da superfície, eu estou lá longe,... uma espécie de sombra que me dá a mim mesmo minha própria visibilidade, que me permite me olhar lá onde estou ausente: utopia do espelho. Mas é igualmente uma heterotopia, na medida em que o espelho existe realmente, e que tem, no lugar que ocupo, uma espécie de efeito retroativo; é a partir do espelho que me descubro ausente no lugar em que estou porque eu me vejo lá longe (FOUCAULT, 2001b, p.415).
} 
Em suma, para que haja utopia, basta que haja um corpo. E nesse corpo, a cabeça impera como um dos elementos primordiais que vitalizam os poderes utópicos do corpo.

Toda essa breve retomada histórica da valorização da cabeça, como porta para ascender à discursividade dos acontecimentos que passaremos a expor, visa a destacar que, desde os primórdios, o enunciado Cortem-lhe a cabeça bradado pela Rainha de Copas arregimenta sentidos que associam a cabeça aos elementos guerreiros, à coragem, à forca física e até mesmo ao esperma, atributos fortes na constituição da virilidade. Soma-se a isso a possibilidade de tomar a cabeça como a "porta de entrada" para a utopia profunda e soberana do corpo.

\section{Cortem-lhe a cabeça no cerne do dispositivo de poder patriarcal}

Cortem-lhe a cabeça é materialidade de um enunciado ligado a uma memória formatada em jogos de poder-saber que produziram verdades sobre os sujeitos. Dentre as principais verdades forjadas no cerne do poder patriarcal, destaca-se o que Witzel (2018, p.131) resume:

a emergência da noção de sexo único, sendo o corpo da mulher uma
mera inversão (sempre imperfeita) do corpo do homem, daí ela ser
hierarquicamente menos importante, menos inteligente, mais
submissa, mais dependente; (ii) a naturalização das diferenças entre
homens e mulheres e, consequentemente, a definição assimétrica dos
papéis sociais atribuídos a cada um (...); (iii) a sacralização da
castidade e da fragilidade de um corpo misterioso (sangra e não
morre), instável, cíclico, cheio de humores, incontrolável e
ameaçador.

São jogos de verdade em meio aos quais o corpo pode ser analisado, decifrado, segundo termo de Courtine (2013), como uma matéria significante (re)produtora de sentidos, imersa na história e fabricada discursivamente; ou seja, o acontecimento do corpo decapitado de uma mulher, quer seja de modo real ou simbólico, implica o encontro de um corpo historicamente subjugado com uma prática milenar que alcança nossos dias acolhida por uma sociedade modernamente controlada por sofisticadas tecnologias digitais, por dispositivos de poder que impõe, não sem resistências, modos de existência normalizado e normatizado por instituições sem muros que alcançam seus objetos com seus tentáculos, em qualquer espaço.

Não se trata, portanto, de uma matéria física e anatômica decapitada, com cerceamento de suas paixões e humores, mas de um corpo tomado como acontecimento 
na história, irrompendo como objeto do discurso nas ciências humanas no início do século XX. Nesse corpo - que possui uma história estética, moral, física, política, ideal e material, passível de ser transformada no tempo e no espaço - a diferença entre os sexos se impõe como condição de emergência de discursos que instalaram o corpo, especialmente o da mulher, de maneira imediata e específica no centro das relações de poder (PERROT, 2007; 1992).

Um corpo sem acesso ao saber e ao pensar, metaforicamente, como vimos, associado à cabeça. Saber e pensar sempre foram o contrário da feminilidade. Lembremo-nos de que toda educação das meninas, tal como defendia Rousseau, deveria ser relativa aos homens. No século XIX, por exemplo, na França, um projeto de lei proibia as mulheres de aprenderem a ler, argumentando: "a intenção da boa e sábia natureza foi de que as mulheres, exclusivamente ocupadas com as tarefas domésticas, se sentissem honradas de segurar em suas mãos não um livro ou uma pena, mas uma roca ou um fuso" (PERROT, 2007, p.92). Um mulher poeta era uma monstruosidade moral e literária; da mesma forma, um soberano mulher era uma mostruosidade política.

$\mathrm{Na}$ soma de inúmeros critérios arbitrários de diferenciação entre os sexos, o poder patriarcal definiu uma importante clivagem: aos homens, "o cérebro [...] a inteligência, a razão lúcida, a capacidade de decisão. Às mulheres, o coração, a sensibilidade, os sentimentos" (PERROT, 1992, p.177, grifos nossos). Enfim, é fácil notar que resquícios desses saberes (de ordem filosófica, religiosa, jurídica, médica etc), atados às tecnologias do poder, atravessaram o tempo reproduzindo verdades perenes, muitas delas devastadoras/mortais nos processos de subjetivação das mulheres.

Não poucas, num espírito de Alice, entendiam que essa condição era um "disparate"; ao refutarem tanto o discurso da incompetência da mulher para ocupar um lugar de liderança, quanto o discurso da dependência e submissão que alicerçou e manteve a estrutura do patriarcado, muitas foram decapitadas real e simbolicamente.

Na história de decapitação real, as mulheres, em regra, eram condenadas por motivos semelhantes aos que levavam os homens à guilhotina, quando essa passou a ser o instrumento que substituiu o enforcamento ou mesmo o machado/espada nas condenações à pena de morte. A rainha francesa Marie Antoniette foi decapitada em 1793, meses após o rei Louis XVI, e ambos foram acusados e condenados por terem "traído o povo francês". Contudo, outras morreram porque eram mulheres e porque transgrediram regras rígidas de uma sociedade patriarcal. Das que entraram para a história, lembremo-nos de Ana Bolena (1507-1536), uma das esposas do rei Henrique 
VIII, da Inglaterra, condenada à morte por suspeitas de adultério, traição e incesto. Destacamos, ainda, Marie-Louise Giraud (1903-1943), guilhotinada em 1943 por ser abortista. Ela contrariava as leis e as doutrinas religiosas que criminalizam o aborto, tema importante e atual nas pautas feministas.

Destacamos, ainda, que a Revolução Francesa foi palco de um acontecimento que deixa claro o destino de mulheres que ousavam ser Alice e romper o silêncio da sua existência. Sob as reivindicações de Liberté, Fraternité e Egalité, Olympe de Gouges (1748-1793), autora da Déclaration des droits de la femme et de la citoyenne, opôs-se ao patriarcado da época. Devido a seus escritos, e a sua desobediência atrelada às atitudes pioneiras nos movimentos feministas, foi guilhotinada.

\section{Regularidades e singularidades do acontecimento cortem-lhe a cabeça}

Sob a ótica arqueológica, um acontecimento discursivo provoca uma ruptura e/ou uma regularidade histórica. Os acontecimentos que destacamos, ao serem consideradas as condições de existência que determinam a materialidade própria do enunciado, indicam (i) uma regularidade que repete práticas de decapitação muito antigas, notadamente as que tomam a cabeça como um símbolo do triunfo desde tempos quase imemoriais; (ii) e uma singularidade, na medida em que a prática da decapitação, embora não rompa a continuidade histórica, ela ressurge como um "novo presente". No encalço da atualidade do imperativo soberano que determina a decapitação, passamos a descrever como este enunciado pôde se formar historicamente e em quais realidades sociais e culturais - se articula.

A partir das palavras-chave "decapitação", "feminicídio" no Google, em março de 2021, foi possível muito rapidamente ter acesso a um sem número de reportagens evidenciando as regularidades e/ou singularidades a partir da atualidade do enunciado Cortem-lhe a cabeça. São acontecimentos discursivos que se somam a uma trágica estatística, na medida em que, segundo o Fórum Brasileiro de Segurança Pública ${ }^{5}$, o Brasil se destaca como um dos países mais violentos para as mulheres. Em 2017, foram registrados 4.539 assassinatos de brasileiras e em $71 \%$ desses casos, o agressor era o parceiro ou ex-parceiro da vítima.

\footnotetext{
${ }^{5}$ Disponível em: http://www.forumseguranca.org.br/wp-content/uploads/2019/03/Anuario-Brasileiro-deSeguran\%C3\%A7a-P\%C3\%BAblica-2018.pdf Acesso em: 10 set 2019.
} 
Os acontecimentos discursivizados e selecionados nos aproximam, interdiscursivamente, das análises que Michel Foucault (1977) propôs com relação ao parricida Pierre Rivière. Eles nos atingem em suas narrativas cuja mola essencial é o conflito entre os sexos protagonizado por sujeitos infames (FOUCAULT, 2006). Embora a mãe de Pierre Rivière tenha recebido pouca atenção do filósofo, é ela que desencadeia, segundo a confissão do parricida, toda a tragédia. E sua morte ocorre, fundamentalmente, porque ela era uma mulher que transgredia as normas do patriarcado. Tomadas em seu conjunto, deparamo-nos com narrativas inscritas nessa mesma (des)ordem discursiva. Vejamos:

\begin{tabular}{|c|c|}
\hline PIERRE RIVIÈRE (1835) & OUTROS INFAMES (2020) \\
\hline $\begin{array}{ll} & \text { sujeito infame } \\
& \text { mata a mãe porque é mulher } \\
& \text { degola a vítima } \\
& \text { revela a violência do conflito entre os } \\
\text { sexos } \\
>\text { Por que mata? Porque "não é justo } \\
\text { [...] que eu deixe viver uma mulher } \\
\text { que perturba a tranquilidade, a } \\
\text { felicidade de meu pai... - é tempo de } \\
\text { construir um exemplo para derrubar a } \\
\text { moral deste século [...] desta nação, } \\
\text { que parece ter tanto gosto pela } \\
\text { liberdade e pela glória, [mas] } \\
\text { obedece às mulheres". } \\
\text { (FOUCAULT, 1977, p.202). }\end{array}$ & $\begin{array}{l}>\text { sujeitos infames } \\
>\text { matam a namorada /esposa/ } \\
\text { companheira porque são mulheres } \\
>\text { degolam a vítima } \\
>\text { revelam a violência do conflito entre } \\
\text { os sexos } \\
>\quad \begin{array}{l}\text { Por que matam? Por ciúme, traição, } \\
\text { insubmissão, desobediência, etc }\end{array}\end{array}$ \\
\hline
\end{tabular}

Rivière se mostra um justiceiro. Toma o lugar do pai que ele julgava fraco demais e, porque desenvolveu uma repulsa pela mãe e pelo poder que ela exercia, decide matá-la. Em sua descrição, a mãe emerge como um ser perdulário, que recusava o sexo e o leito comum. Além disso, ela controlava as despesas do marido e possuía suas próprias economias ${ }^{6}$, um despropósito se consideradas as práticas que determinavam total dependência e submissão das mulheres da época de Rivière.

Nos outros acontecimentos, os sujeitos também se mostram, em grande parte, como justiceiros. Ao justificarem seu crime, destaca-se o fato de se considerarem traídos e, tal como se sedimentou na história de controle dos corpos, centrada na moral e

\footnotetext{
${ }^{6}$ Lembremo-nos de que, nas antigas leis francesas, a mulher era subordinada a seus irmãos e, depois, a seu marido; somente poderiam gerenciar seus bens ou herança se fossem filhas únicas ou solteiras. Do contrário, os irmãos ou o marido tinham o direito de dispor de suas propriedades. Essa situação somente foi modificada depois da Revolução Francesa, em 1789.
} 
na assimetria das relações, o adultério da mulher sempre foi um gravíssimo atentado à honra e à dignidade do homem. Quantas narrativas nos atualizam essa prática de matar por ciúmes e/ou em legítima defesa da honra? Esses sujeitos, ao lavarem a honra com sangue, saem da obscuridade porque se chocam com o poder; mediante a narrativa de seus crimes, suas vidas infames tocam a eternidade. (FOUCAULT, 2006, p. 117).

Fugiria dos propósitos deste estudo analisar a prática criminal em si ou mesmo abordar as diferentes teorias ancoradas em aspectos biológicos, psicológicos, sociológicos etc. Interessa-nos a dimensão histórica que constitui os discursos/acontecimentos que coloca em relevo o fato de que a formação do arquivo e da memória sobre o ser mulher sempre se deu por meio de certa fixação seletiva de discursos produzidos pelas/nas relações de poder e pelos/nos sistemas de valores sóciohistórico-culturais (WITZEL, 2014). Ao cortarem a cabeça das mulheres, esses acontecimentos - ligados a tantos outros - retomam os saberes históricos tomados como saberes verdadeiros em torno da simbologia da "cabeça" atravessada por mitos e vontades de verdade.

Dentre os comentários que seguem as notícias, repetem-se enunciados que, novamente, nos rementem ao Pierre Rivière. Destacam-se "louco" e "monstro". São enunciados que implicam uma biopolítica definidora do infame, ou seja, o ser objetivado e subjetivado pela infâmia, desregrado e marginal. Em regra, os homens infames são aqueles desonrados, desacreditados, insignificantes. Contudo, destaca Foucault:

O insignificante cessa de pertencer ao silêncio, ao rumor que passa ou à confissão fugidia. Todas essas coisas que compõem o comum, o detalhe sem importância, a obscuridade, os dias sem glória, a vida comum, podem e devem ser ditas, ou melhor, escritas. Elas se tornaram descritíveis e passíveis de transcrição, na própria medida em que foram atravessadas pelos mecanismos de um poder político. (FOUCAULT, 2006, p. 216)

Louco e mostro apontam para esses mecanismos, na medida em que estão investidos de sentidos atrelados à repulsa e à censura que podem se referir tanto ao parricida que degolou ${ }^{7}$ a mãe (o irmão e a irmã) para salvar a honra do pai, quanto aos demais sujeitos tomados como anormais. Eles são identificados como monstros e/ou loucos, em meio a outras designações correlatas referentes àqueles que burlam as regras de sociabilidade, civilidade e normalidade. Com efeito, a infâmia depende da alteridade,

\footnotetext{
7 Degolar e decapitar são tomados, aqui, como sinônimos.
} 
da opinião/atitude/julgamento do outro, este que tem seus alicerces morais e éticos agredidos.

Pierre Rivière faz parte das "vidas de algumas linhas ou de algumas páginas, desventuras e aventuras sem nome, juntadas em um punhado de palavras. Vidas breves, encontradas por acaso em livros e documentos (FOUCAULT, 2006). Os outros infames não são diferentes, pois suas vidas, também breve, são encontradas por acaso nas manchetes jornalísticas, vidas efêmeras que se consagram perenes na heterotopia da web (GREGOLIN, 2015). A infâmia cede lugar para a fama por força da nova cartografia do espaço visível criado na era digital.

A mídia há muito é um espaço do espetáculo, estudado por Guy Débord; mas a mídia digital e seus desdobramentos reclamam gestos de interpretação de uma nova linguagem que (re)produz e expõe subjetividades. É a partir da relação que o corpo estabelece com o espaço que Foucault, notadamente em sua História da Sexualidade, focaliza a produção de subjetividade. Apesar do nó profundo com o tempo, é o espaço que preocupa o filósofo: "nossa época talvez seja, acima de tudo, a época do espaço [...]

Nós vivemos na época da simultaneidade: nós vivemos na época da justaposição, do próximo e do longínquo, do lado-a-lado e do disperso. Julgo que ocupamos um tempo no qual a nossa experiência do mundo se assemelha mais a uma rede que vai ligando pontos e se intersecta com a sua própria meada do que propriamente a uma vivência que se vai enriquecendo com o tempo (FOUCAULT, 2001, p.411).

Sua análise foi feita na década de 1960, mas poderia ter sido feita esta semana. Se o navio é a metáfora primordial da heterotopia até o século XX (FOUCAULT, 2001; 2013), a web se transformou em uma heterotopia por excelência do século XXI. Nesse espaço virtual,

cruzam-se todo tipo de outros espaços consensuais e conflitantes, acolhem-se todo tipo de enunciados e de formas de visibilidades numa cartografia em que se misturam permissividade e controle de forma ambígua; o seu funcionamento tem em sua base o contínuo movimento do dito e do não dito. Navegaremos por esse labirinto e a velha metáfora da navegação convive com outras formas de experimentar lugares nunca dantes navegados (GREGOLIN, 2015, p.202)

Um espaço, portanto, que acolhe, na atualidade, os símbolos que antes eram expostos em praça pública (cabeça de Tiradentes) ou exibidos em cortejos fúnebres (cabeça da Maria Bonita), que passam a ganhar imensa visibilidade nessa heterotopia da web. São corpos que, na esteira de Foucault, reinventam-se como um ator utópico, 
porque são arrancados de seu espaço próprio e projetados em um "espaço outro" (FOUCAULT, 2013, p.12).

\section{Considerações finais}

Ao nos propormos fazer uma arqueologia do enunciado Cortem-lhe a cabeça, retornamos à história da simbologia da cabeça cortada para, em seguida, olharmos para os infames, seguindo Foucault, um cartógrafo das margens, um historiador do corpo, do poder e dos espaços, que argumenta que é na investigação dos acontecimentos periféricos, daqueles deixados à margem da história, que se ouve o rachar das estruturas. E imbuídos desse espírito de "rachar as estruturas" que encerramos este texto retomando a Alice.

Qual foi seu crime para a Rainha ordenar (sem julgamento) a sua decapitação? $\mathrm{Na}$ complexa configuração dessa personagem, vale pensarmos nas identidades do feminino e nos processos de subjetivação na contemporaneidade, considerando que ela se sobressai como uma menina curiosa: ela, o tempo todo, quer saber, conhecer, entender... daí a liderar, governar, ocupar os espaços tradicionalmente viris é uma consequência.

Ela não aceita a sentença da rainha, considerando-a um "disparate", um "absurdo". No (im)possível país das maravilhas, representa-se o exercício do poder funcionando, necessariamente, com a liberdade de resistir (FOUCAULT, 1995). Ou seja, em sendo o poder relação de forças, há sempre a possibilidade de um contraexercício: a resistência. Para Foucault (1995), as mudanças nas relações de poder podem encerrar uma situação de dominação e incrementar possibilidades de liberdade

Diz Foucault:

Gostaria de dizer algo acerca das funções de qualquer diagnóstico concernente à natureza do presente. Não consiste em uma simples caracterização do que somos, mas em vez disso - seguindo linhas de fragilidade no presente - em conseguir apreender a razão pela qual e como isso-que-é poderia já não ser isso-que-é. Nesse sentido, qualquer descrição deve sempre ser feita de acordo com estes tipos de fraturas virtuais que abrem o espaço da liberdade entendida como um espaço de liberdade concreta, ou seja, um espaço de possível transformação. (FOUCAULT, apud MAY, 2011, p.107-108). 
Nessa direção, o enunciado Cortem-lhe a cabeça que incidiu sobre a mãe de Pierre Rivière e sobre tantas outras evidenciou cabeças que irrompem como símbolo de poder e de justiça. Elas se somam àquelas cuja liberdade foi usurpada pelo poder patriarcal - não mais soberano - mas que formata, constrange ou mesmo nega a liberdade de mulheres, decapitando-as tanto no sentido real quanto no simbólico.

\section{REFERÊNCIAS BIBLIOGRÁFICAS}

CARROLL, L. Alice no País das Maravilhas. São Paulo: Martin Claret, 2007.

COURTINE, J.J. Decifrar o corpo. Pensar com Foucault. Petrópolis, RJ: Vozes, 2013. FOUCAULT, M. O corpo utópico; As heterotopias. São Paulo, N-1 Edições, 2013. Arqueologia do Saber. Rio de Janeiro: Forense Universitária, 2007

A vida dos homens infames in: Ditos e escritos, v. 4. Rio de Janeiro: Forense universitária, 2006.

Vigiar e Punir: nascimento da prisão. Petrópolis, RJ: Vozes, 2005.

Dos outros Espaços. In: MOTTA, M. B. (Org.). Michel Foucault Estética: Literatura e Pintura, Música e Cinema. Rio de Janeiro: Forense Universitária, 2001. p.411-422.

O sujeito e o poder. In: RABINOW, P.; GREYFUS, H. Michel Foucault. Uma trajetória filosófica. Rio de Janeiro: Forense Universitária, 1995, p.231-249.

Les vies parallèles. In. Dits et écrits II (1976-1988). Paris: Gallimard, 1994.

Eu, Pierre Rivière, que degolei minha mãe, minha irmã e meu irmão: um caso de parricídio do século XIX. Rio de Janeiro: Graal, 1977.

GREGOLIN, R. Discursos e Imagens do corpo: heterotopias da (in)visibilidade na web. In: Flores, G.; Necket, Nádia; Gallo, S. (Orgs). Análise do Discurso em Rede: Cultura e Mídia. Campinas: Pontes, 2015.

MAY, T. A concepção de liberdade de Foucault. IN. TAYLOR, D. (Org.) Michel Foucault-conceitos fundamentais. São Paulo: Vozes, 2018, p.97-113.

NEGREIROS, A. Maria Bonita: Sexo, violência e mulheres no cangaço. Rio de Janeiro: Objetiva, 2018.

PERROT, M. Minha história das mulheres. São Paulo: Contexto, 2007.

Os Excluídos da História. Rio de Janeiro: Paz e Terra, 1992.

ZIERER, A. Simbologia da cabeça cortada entre os Celtas e algumas analogias com o mito da Górgona. Phoinix, Rio de Janeiro, 17-1: 112-129, 2011. 
WITZEL, D.G. Parirás na dor: mulheres em choque com o poder. Interfaces, vol. 9, n. 4: 124-133, 2018.

. Discurso, história e corpo feminino em antigos anúncios publicitários. Alfa, São Paulo, 58 (3): 525-539, 2014. 